\title{
The mediating role of organizational commitment of job performance: The Impacts of Leadership, job competency and organizational culture
}

\author{
Suriadi \\ Lecturer in Muhammadiyah University of Buton, \\ Southeast Sulawesi \\ Mursalim Umar Gani \\ Professor in Management, Postgraduate School, \\ Moslem University of Indonesia, Makassar \\ Muh, Nasir Hamzah \\ Professor in Management, Postgraduate School, \\ Moslem University of Indonesia, Makassar \\ Zainal Arifin \\ Lecturer in Management, Postgraduate School, \\ Moslem University of Indonesia, Makassar
}

\begin{abstract}
The purpose of this paper is to examine the mediating role of organizational commitment of job performance: The Impacts of leadership, job competency and organizational culture. Data were gathered through questionnaires. Data collected from 254 employees working on the eight work units on the Southeast Sulawesi regional government office. The structural equation modeling (SEM) results indicate that: (1) leadership, job competence, and organizational culture partially have a direct effect on organizational commitment, (2) leadership, job competence, and organizational culture partially have a direct effect on job performance, (3) leadership, job competence, and organizational culture partially have a direct effect on job performance, with the mediating role of organizational commitment.
\end{abstract}

Keywords: Leadership, job competence, organizational culture, organizational commitment, job performance.

\section{INTRODUCTION}

Since the New Order era in Indonesia the bureaucracy grew as an instrument for developing industrialization and modernizing society. Bureaucratic reform basically aims to create a government bureaucracy that is professional with adaptive characteristics, integrity, high performance, clean, capable of serving the public, neutral, prosperous, dedicated, and upholding the basic values and code of ethics of the state apparatus. Bureaucratic reform is a manifestation of the government's ongoing commitment and change in mindset and culture. Meanwhile, to accelerate the success of the process of changing the mindset and work culture of the apparatus in the local government office, a reference can be used as a basis in the form of guidelines to encourage changes in attitudes and behavior of officials and employees within the local government office.

Based on the Government Regulation of the Republic of Indonesia Number 46 of 2011 concerning employee performance appraisal concerning the work implementation assessment 
list (DP3) and Regulation of the Head of the National Personnel Agency (Perka. BKN) Number 1 of 2013, that the work performance appraisal system into the new paradigm with a more comprehensive and objective element. Performance is the implementation of the plan that has been prepared, where the implementation of performance is carried out by human resources who have the ability, competence, motivation and interests (Wibowo, 2014). While employee performance is the work achievement achieved by an employee quantitatively and qualitatively measured by performance standards. As for several factors that contribute to employee performance, such as leadership, competence, organizational culture, and organizational commitment. Leadership is a factor that can affect employee performance.

Leadership is the way a leader influences the behavior of subordinates, so they want to work together and work productively to achieve organizational goals (Hasibuan, 2006). Competence can be described as the ability to carry out one task, role or task, the ability to integrate knowledge, skills, attitudes and personal values, and the ability to build knowledge and skills based on experience and learning done (Roe, 2001) Several factors can influence a person's competency skills such as beliefs and values, skills, experience, personality characteristics, motivation, emotional issues, intellectual abilities, and organizational culture (Zwell, 2000).

The strong culture of all employees is the key to the success of an organization (Moeheriono, 2012). Organizational culture is a culture of knowledge acquired to interpret experiences and produce social behavior. Organizational culture is norms and values that direct the behavior of organizational members (Luthan, 2006). Some previous studies, (i.e. Arief, 2011; Alotaibi, 2001; Bello, 2012; Koech \& Namusonge, 2012; Hamzah, 2013; Ade \& Noermijati, 2013; Toban \& Sjahruddin, 2016; Sari \& Sjahruddin, 2018; Sahara et al. , 2018), which generally provides evidence that leadership, competence and organizational culture partially have a positive and significant effect on employee performance. These results received rebuttal from other researchers (Stander \& Coxen, 2017). That leadership has a negative and insignificant effect on organizational commitment. A similar fact was found in a study conducted by Panjisadewa (2015) that leadership had a positive and not significant effect on employee performance. The difference in findings is caused by the management style that is applied differently in each organization so that it influences the leadership behavior towards the employee.

Furthermore, to produce a good leadership style, competence and strong organizational culture, the commitment of employees to the organization has an important role. Employee commitment to the organization is expected to further improve employee performance and provide benefits to the organization. Organizational commitment is an attitude that must be owned by every employee. Commitment is a binder that gives encouragement to give what is best for what is their responsibility. Organizational commitment is related to a sense of identification, loyalty, and involvement expressed by an employee to an organization or organizational unit (Gibson et al., 2000: 186).

The results of previous studies provide evidence that leadership has a positive and significant effect on employee performance through organizational commitment (Permata, 2017). The same fact proved by other researchers that organizational commitment has a positive and significant influence in mediating between employee competencies and employee performance (Sriekaningsih \& Setyadi, 2015). Organizational culture has a positive and significant effect on employee performance through organizational commitment (Yamali, 2018).

This research was conducted at the Southeast Sulawesi provincial government office. The unit of analysis is employees who work in various bureaus (i.e. government administration 
bureaus, administration of public welfare and society, law, development administration, public relations, organization, general affairs, and procurement services). The performance appraisal and results achieved are reviewed from several aspects such as human resource management $(8 \%)$, leadership (6\%), measurement of work information analysis and management (9\%), process management (8\%), achievement of results $(45 \%)$, budgeting $(4 \%)$, performance planning (14\%), and organization (6\%). The results of performance achievements in each aspect indicate that the need to improve employee performance through leadership, competence, organizational culture, which is supported by employee commitment to the organization.

\section{Leadership}

\section{LITERATURE REVIEW}

Leadership is a process that influences the behavior of other people to behave as they would like (Nimran, 2004). Leadership is more than just a set of skills and expertise. Leadership has subtle personal qualities that are rather difficult to see, but very influential. There are several types of leadership, including charismatic types, paternalistic and materialistic types, militaristic types, autocratic leadership, laissez faire, populist types, administrative types, and democratic types (Malayu Hasibuan, 2006). Several leadership models, namely contingency leadership model, leader participation model by Vroom and Yetton, goal path model and situational leadership by Hersey - Blanchard (Rivai Veithzal, 2003).

\section{Job competency}

Competencies can be described as the ability to carry out one task, role or task, the ability to integrate knowledge, skills, attitudes and personal values, and the ability to build knowledge and skills based on experience and learning (Roe , 2001). Classification of types of competencies is usually seen from the human dimension personally because humans are social beings. Basically, humans have three dimensions, namely (1) body, (2) mind and (3) soul and on the basis of these dimensions, they classify competencies into three, namely intellectual, emotional and spiritual competencies (Zohar \& Marshall, 2000; Willy Susilo, 2010: 17). The views of other scholars, classify dimensions and components of individual competencies, namely; intellectual, emotional and social competence. Components of competence from human dimensions and relationships between personal, but have not produced a component of spiritual competence. The main characteristics of competencies will be effect on job performance, namely motives, traits, self-concept, knowledge and skills (Spencer \& Spencer, 1993).

\section{Organizational culture}

Organizational culture is a shared value system in an organization that becomes a reference for how employees carry out activities to achieve organizational goals or ideals. This is usually stated as the vision, mission and goals of the organization. Organizational culture is developed from a collection of norms, values, beliefs, hopes, assumptions, and philosophies of the people in them. Culture can be defined as knowledge gained to interpret experiences and produce social behavior. Organizational culture is the norms and values that direct the behavior of organizational members. Each member will behave with a culture that has been applied to be accepted by the environment (Luthan, 2006: 47). Other scholars provide organizational culture characteristics, such as (innovation and risk taking), attention to details, results orientation, people orientation, team orientation, aggressiveness and stability (Robbins \& Judge, 2008: 256). 


\section{Organizational commitment}

Organizational commitment is an attitude that must be owned by every employee. Commitment is a binder that gives an impetus to give what is best to what is their responsibility (Luthans, 2006). Organizational commitment is a sense of identification, loyalty, and involvement expressed by an employee to an organization or organizational unit. Organizational commitment to three components, namely affective commitment, continuance and normative (Allen \& Meyer, 1990)

\section{Job performance}

Performance is reflected in the concrete forms of work performance applied by an organization by actualizing a series of work activities according to service, activity, results, handling, benefits and accountability. Performance is a function of motivation and ability. Performance is also a real behavior that is displayed by everyone as the work performance produced by employees in accordance with their role in the company (Rivai, 2004). Employee performance is a very important thing in an effort to achieve goals through the ability to achieve job requirements (Mangkunegara, 2005).

\section{RESEARCH FRAMEWORK}

The relationship between research variables is built based on relevant theories and results of previous studies. Theoretical reviews and empirical findings are used as the basis for describing the conceptual framework of the research and are used as the basis for deriving the research hypothesis. Leader behavior or leadership is one of the important factors that can affect job satisfaction. Leadership style has a positive relationship to job satisfaction of employees (Russell \& Gregory, 2002). Leadership is a pattern of consistent behavior that they implement in working with others through consisting of directive leadership, supportive leadership, participatory leadership and achievement-oriented leadership (Hersey \& Blanchard, 1969). The creation of high performance is supported by competence, that competence is the basic foundation of people's characteristics and indicates how to behave or think, equate situations, and support for a long period of time (Spencer \& Spencer, 1993). Competencies can be in the form of motives, traits, self-concepts, attitudes, or values of cognitive skills or behaviors of individual characteristics (Rivai, 2009: 426).

The better attitude should be developing competencies, the more important of the human resources quality (Wellance, 2007: 54). Competence is a key determining factor for someone in producing excellent performance (Rivai, 2009: 425). Based on the fact that there are many factors other than the above factors that affect employee performance, there are also cultural factors in the workplace. The success of a company is determined by its success in creating a distinctive organizational culture as part of their strategic plan. Effective organizational culture includes good pay and rewards that will improve employee performance (Yanow \& Adams, 2018). Organizational culture is as values, principles, traditions and ways of working that are shared with the members of the organization in influencing the way they act (Robbins \& Judge, 2008)

The other factors effect on job performance, namely organizational commitment which is an attitude that must be owned by each employee. Commitment is a binder that gives encouragement to give what is best for what is their responsibility. Employee commitment to the organization is not something that happens unilaterally. In this case the organization and employees (individuals) must jointly create conditions conducive to achieving the intended commitment. One of the factors suspected of having a determinant of employee performance is organizational commitment. This is because organizational commitment can be seen as a factor 
that can hold employees to survive and provide the best for the organization. Organizational commitment is a condition where employees are not only physically bound by the organization, but are also able to devote their best thoughts, attention, and dedication to the progress of the organization (Lambert, 2018). Quantitative and qualitative measures will be describing the level of achievement of an activity (Moeheriono, 2012: 115).

Performance is a means to get better results from organizations, teams and individuals by understanding and managing performance within the framework of goals and standards, and agreed attribute requirements (Armstrong \& Baron, 1998). Some previous studies (i.e. Ade \& Noermijati, 2013; Arief, 2011; Bello, 2012; Alotaibi, 2001; Koech \& Namusonge, 2012; Hamzah et al., 2013; Toban \& Sjahruddin, 2016; Sari \& Sjahruddin, 2018; Sahara et al., 2018), which generally states that leadership, competence and organizational culture partially have a positive and significant effect on employee performance. The debate over the results of the study provides new evidence that leadership has a negative and insignificant effect on organizational commitment (Stander \& Coxen, 2017). The results of these studies support the findings of other researchers, that leadership has a positive and not significant effect on job performance (Panjisadewa, 2015).

In other causality it is shown that leadership has a positive and significant effect on employee performance through organizational commitment (Permata, 2017). Then it was also proven that organizational commitment has a positive and significant influence in mediating between competency and employee performance which is operationalized as an embodiment of employee service quality (Sriekaningsih \& Setyadi, 2015). Other results show that organizational culture has a positive and significant effect on employee performance through organizational commitment (Yamali, 2018).

Based on theoretical and empirical studies and previous research we will analyze the hypothesis:

1. Leadership, job competency and organizational culture partially have a significant positive direct effect on organizational commitment

2. Leadership, job competency and organizational culture will have a direct positive effect on job performance

3. Leadership, job competency and organizational culture will have an indirect positive effect on job performance, the mediator effect of organizational commitment.

\section{Descriptive variables}

\section{RESULTS}

The results of the average value in the variable description indicate that the perceptions of employees are at the level of satisfaction or height towards indicators and constructs that are formed from variables of leadership, competence, organizational culture, organizational commitment and employee performance at the Southeast Sulawesi government office.

Table 1. Descriptive

\begin{tabular}{lclc}
\hline \multicolumn{1}{c}{ Construct } & Mean $(\mu)$ & \multicolumn{1}{c}{ Indicator } & Mean $(\mu)$ \\
\hline Leadership & 4.60 & Work performance oriented leadership & 4.78 \\
Job competency & 4.14 & Knowledge & 4.21 \\
Organizational culture & 4.03 & Integrity & 4,37 \\
Organizational commitment & 4.20 & Work Motivation based on benefits & 4.29 \\
Job Performance & 4.14 & Output & 4.28 \\
\hline
\end{tabular}




\section{Testing the validity of the measurement model and structural model}

Test the validity of the measurement model aimed at knowing the correlation and the real relationship between indicators against each construct. Indicators that have a strong and real relationship can be known through the value of loading factors and probability values. The value of loading factor shows the correlation coefficient $(r)$ of each indicator against the construct $(r=\geq 0.7)$ and the probability value indicates a real relationship ( $p$-value $=\leq 0.05$ ). The results of confirmatory factor analysis show that leadership participation $(\mathrm{r}=0.977$; $\mathrm{p}$ value $=\leq 0.05)$, self-concept $(r=0.848$; $p$-value $=\leq 0.05)$, responsibility $(r=0.908$; $p$-value $=\leq$ $0.05)$; trust $(r=0.831$; $p$-value $=\leq 0.05)$, has a strong and real positive relationship with each construct (Sjahruddin \& Sudiro, 2013).

Test the validity of the structural model shows the relationship between the independent variables on the dependent variable or the presence of covariance. The validity of the model is indicated by the Goodness of Fit Index which shows whether the model formed is in accordance with the empirical data collected through the sample. The results of goodness of fit indicate that all criteria have met the value of cut off value so that the model formed is in accordance with the empirical data obtained.

Table 2. Goodness of fit

\begin{tabular}{cccc}
\hline Measurement & Cut-off value & Model results & Description \\
\hline Chi square $\left(x^{2}\right)$ & Small expected & $292,17 \leq(0.05: 254=192,259)$ & Good \\
Probability & $\geq 0,05$ & 0,190 & Good \\
CMIN/DF & $\leq 2,00$ & 1,090 & Good \\
RMSEA & $\leq 0,08$ & 0,019 & Good \\
GFI & $\geq 0,90$ & 0,944 & Good \\
AGFI & $\geq 0,90$ & 0,904 & Good \\
TLI & $\geq 0,95$ & 0,995 & Good \\
CFI & $\geq 0,95$ & 0,997 & Good \\
\hline
\end{tabular}

\section{Hypothesis}

Based on the results of hypothesis testing, it appears that the probability value $=<0.05$ and direct and indirect effect values show a positive direction, so it can be concluded as follows:

1) Leadership, job competency and organizational culture partially have a significant positive direct effect on organizational commitment.

2) Leadership, job competency and organizational culture partially have a significant positive direct effect on job performance.

3) Leadership, job competency and organizational culture partially have a significant positive effect on job performance through organizational commitment. 
Table 3. Hypothesis testing

\begin{tabular}{|c|c|c|c|c|c|c|c|}
\hline Exogenous & $\begin{array}{r}\text { Variable } \\
\text { Mediation }\end{array}$ & Endogenous & P-Value & $\begin{array}{l}\text { Direct } \\
\text { Effect }\end{array}$ & $\begin{array}{l}\text { Indirect } \\
\text { Effect }\end{array}$ & $\begin{array}{l}\text { Total } \\
\text { Effect }\end{array}$ & Results \\
\hline Leadership & & $\begin{array}{l}\text { Organizational } \\
\text { commitment }\end{array}$ & 0,000 & 0,312 & - & 0,312 & $\begin{array}{l}\text { Positive } \\
\text { Significant }\end{array}$ \\
\hline Job competency & & $\begin{array}{l}\text { Organizational } \\
\text { commitment }\end{array}$ & 0,000 & 0,570 & - & 0,570 & $\begin{array}{l}\text { Positive } \\
\text { Significant }\end{array}$ \\
\hline $\begin{array}{l}\text { Organizational } \\
\text { culture }\end{array}$ & & $\begin{array}{l}\text { Organizational } \\
\text { commitment }\end{array}$ & 0,043 & 0,187 & - & 0,187 & $\begin{array}{l}\text { Positive } \\
\text { Significant }\end{array}$ \\
\hline Leadership & & Job performance & 0,020 & 0,208 & - & 0,208 & $\begin{array}{l}\text { Positive } \\
\text { Significant }\end{array}$ \\
\hline Job competency & & Job performance & 0,001 & 0,285 & - & 0,285 & $\begin{array}{l}\text { Positive } \\
\text { Significant }\end{array}$ \\
\hline $\begin{array}{l}\text { Organizational } \\
\text { culture }\end{array}$ & & Job performance & 0,020 & 0,137 & - & 0,137 & $\begin{array}{l}\text { Positive } \\
\text { Significant }\end{array}$ \\
\hline $\begin{array}{l}\text { Organizational } \\
\text { commitment }\end{array}$ & & Job performance & 0,018 & 0,237 & - & 0,237 & $\begin{array}{l}\text { Positive } \\
\text { Significant }\end{array}$ \\
\hline Leadership & $\begin{array}{c}\text { Organizational } \\
\text { commitment }\end{array}$ & Job performance & 0,038 & 0,208 & 0,074 & 0,282 & $\begin{array}{l}\text { Positive } \\
\text { Significant }\end{array}$ \\
\hline Job competency & $\begin{array}{c}\text { Organizational } \\
\text { commitment }\end{array}$ & Job performance & 0,022 & 0,285 & 0,135 & 0,420 & $\begin{array}{l}\text { Positive } \\
\text { Significant }\end{array}$ \\
\hline $\begin{array}{l}\text { Organizational } \\
\text { culture }\end{array}$ & $\begin{array}{c}\text { Organizational } \\
\text { commitment }\end{array}$ & Job performance & 0,048 & 0,137 & 0,044 & 0,181 & $\begin{array}{l}\text { Positive } \\
\text { Significant }\end{array}$ \\
\hline
\end{tabular}

\section{DISCUSSIONS}

\section{Effect of leadership on organizational commitment}

Empirical research has shown that leadership is related to efforts to influence other people to want to do the desired work to achieve common goals. A person's leadership can reflect his personal character besides that the impact of his leadership will influence organizational commitment. The results of hypothesis testing from this study indicate that p-value $=0,000<$ 0.05 and the value of loading factor $=0.312$. This means that leadership has a positive and significant effect on organizational commitment. The results of this study are in line with the findings of some previous researchers (i.e. Koesmono, 2007; Yuliawan \& Supartha, 2012; Saladin, 2016; Steffens, 2018), that leadership has a positive and significant effect on organizational commitment. But different findings provide new evidence that leadership has a negative and insignificant effect on organizational commitment (Stander \& Coxen, 2017). The existence of discrepancies with previous research is caused by the leadership style that is applied differently so that it influences the behavior of leaders towards employees.

\section{Effect of job competency on organizational commitment}

Empirical research has shown that shared competencies with commitment are included in the group of individual characteristics of members of the organization. Competence is related to the basic characteristics of a person who influences the way of thinking and acting, generalizes on all situations faced and lasts long enough in human beings. The concept of competence is understood as a combination of abilities and skills (Kreitner \& Kinicki, 2003). The results of the hypothesis test from this study indicate $\mathrm{p}$-value $=0,000<0.05$ and the value of factor loading = 0.570 . This means that job competency has a positive and significant effect on organizational commitment. The research results are in line with previous research, that there are positive and significant influences on organizational commitment (Yamali, 2017; Van Esch et al., 2018).

\section{Effect of organizational culture on organizational commitment}

Organizational culture is a shared value system in an organization that becomes a reference for how employees carry out activities to achieve the goals and ideals of the organization. Organizational culture is closely related to organizational commitment. Harmonization of the 
goals achieved between employees and organizations through culture will build organizational commitment within employees (Lumbanraja, 2009). Hypothesis test results from this study indicate $p$-value $=0.043<0.05$ and the value of factor loading $=0.187$. This means that organizational culture has a positive and significant effect on organizational commitment. The research results are in line with previous research (i.e. Lumbanraja, 2009; Arifin, 2010; Taurisa et al., 2012; Usmany et al., 2016; Dewi \& Surya, 2017), that organizational culture has a positive and significant effect on organizational commitment.

\section{Effect of leadership on job performance}

Leadership is a process of influencing other people to achieve organizational goals. The leadership role in contributing to employees for achieving optimal performance can be carried out through the calcification of what is expected of employees specifically the goals and objectives of performance, explaining how to meet these expectations, expressing criteria for evaluating performance effectively, providing feedback when employees have reached the target, and allocated rewards when employees have achieved the target (Nimran, 2004). The results of hypothesis testing from this study indicate that $\mathrm{p}$-value $=0.020<0.05$ and the value of factor loading $=0.208$. This means that leadership has a positive and significant effect on job performance. The results of this study support the findings of previous researchers, that leadership has a positive and significant effect on job performance (Bello, 2012; Buil et al., 2018; Soemantri \& Sjamsi, 2018).

\section{Effect of job competency on job performance}

Personal aspects such as motives, traits, value systems, attitudes, knowledge and skills, which make it possible for an employee to achieve superior performance are part of competence (Ulrich et al., 2012). Personal aspects through competency will direct behavior and behavior to produce performance. Competence is a basic characteristic of an employee that allows it to provide superior performance in certain jobs or situations (Marshall, 2003). The results of hypothesis testing from this study indicate $\mathrm{p}=0.001<0.05$ and loading factor value $=0.285$. This means that job competency has a positive and significant effect on job performance. The results of this study are in line with the findings of previous researchers that job competency has a positive and significant effect on job performance (Marshall, 2003; Hadiyatno, 2014; Deddy, 2016).

\section{Effect of organizational culture on job performance}

Organizational culture is closely related to job performance. Job performance is the level of work achieved by employees with certain conditions (Simmamora, 2004). Strong organizational culture is the result of the spread of trust and values that develop in the organization and direct the behavior of its employees (Soedjono, 2005). The results of the hypothesis test from this study indicate p-value $=0.020<0.05$ and the value of factor loading = 0.137 . This means that organizational culture has a positive and significant effect on job performance. The research results are in line with previous research that organizational culture has a positive and significant effect on job performance (Soedjono, 2005; Koesmono, 2006; Tanuwibowo \& Sutanto, 2014; Usmany et al., 2016).

\section{Effect of organizational commitment on job performance}

Organizational commitment is a strong desire to remain as a member of a particular organization, the desire to strive in accordance with the wishes of the organization, as well as certain beliefs and acceptance of values and goals of the organization. In other words it is an attitude that reflects employee loyalty to the organization and an ongoing process where members of the organization express their concern for the organization and ongoing success and progress (Luthans, 2006). Hypothesis test results from this study indicate $p$-value $=0.018$ 
$<0.05$ and the value of factor loading $=0.237$. This means that organizational commitment has a positive and significant effect on job performance. The results of this study support the findings of previous researchers that organizational commitment has a positive effect on job performance (Yeh \& Hong, 2012; Ghorbanpour et al., 2014). Refusing the findings of other researchers, that partially organizational commitment does not affect on job performance (Natassia, 2013; Pandaleke, 2016).

\section{Effect of leadership on job performance: The mediating role of organizational commitment}

The Sobel test results show that leadership has a positive effect on job performance through organizational commitment showing p-value $=0.038<0.05$ and Loading factor value $=0.074$. This means that better leadership will further improve job performance because the commitment of employees to the organization is getting stronger. This can be seen from changes direct the total effect of leadership on job performance was 0.228 to 0.282 for total effect. The results of this study are in line with the findings of previous researchers, that leadership has a positive and significant effect on job performance through organizational commitment (Permata, 2017). The results of this study indicate that participatory leadership encourages employees to express ideas so as to encourage employees to increase their commitment to the organization. Employees who have a high commitment will lead to loyalty to the organization so as to higher performance.

\section{Effect of job competency on job performance: The mediating role of organizational commitment}

The Sobel test results show that job competency has a positive effect on job performance through organizational commitment showing $\mathrm{p}$-value $=0,022<0.05$ and Loading factor value $=0.074$. This means that increasingly strong competencies will further improve job performance because the commitment of employees to the organization is getting stronger. This can be seen from changes direct the total effect of job competency on job performance is 0.286 to 0.420 for total effect. The results of this study are in line with previous research that organizational commitment has a positive and significant influence in mediating between job competency and job which is operationalized as an embodiment of service quality (Astuti, 2012).

\section{Effect of organizational culture on job performance: The mediating role of organizational commitment}

The Sobel test results show that organizational culture has a positive effect on job performance through organizational commitment with p-value $0,048<0.05$ and Loading factor value $=$ 0.044. This means that an increasingly strong organizational culture will further improve job performance because the commitment of employees to the organization gets stronger. This can be seen from changes the total effect of competence on job performance is 0.286 to 0.420 for total effect. The results of this study are in line with previous research from the results of this study in line with previous research that organizational culture has a positive and significant effect on job performance through organizational commitment (Yeh \& Hong, 2012). The results of this study indicate that employees who have a strong organizational culture will have high social values that increase trust in the organization. Trust in the organization is realized through commitments that have an impact on improving optimally of job performance.

\section{CONCLUSIONS}

Leadership, competence and organizational culture perceived by employees contribute high and significantly to the organizational commitment of Southeast Sulawesi Provincial Government employees. Leadership, competence and organizational culture that employees perceive give a high and significant contribution to the performance of employees of the 
Southeast Sulawesi Provincial Government. The organizational commitment support shown by employees gives a high contribution in creating employee performance that is influenced by leadership, competence and organizational culture.

To the Southeast Sulawesi provincial government to always prioritize the participatory leadership style because it provides the greatest contribution to the creation of good leadership in the Southeast Sulawesi provincial government office. Improvement of selfconcept in employees is an effort to establish a harmonious relationship between leaders and subordinates because it contributes to the creation of strong competencies for employees.

\section{References}

Ade, R., \& Noermijati, CS (2013). The Influence of Organizational Commitment and Individual Competence on Teacher Performance: In the Learning Organization Perspective. International Journal of Business and Behavioral Sciences 3 (8): 19, 35 .

Allen, NJ, \& Meyer, JP (1990). The measurement and antecedents of affective, continuance and normative commitment to the organization. Journal of occupational psychology, 63 (1), 1-18.

Alotaibi, AG (2001). Antecedents of organizational citizenship behavior: A study of public personnel in Kuwait. Public personnel management, 30 (3), 363-376.

Arief, A. (2011). Effect of Leadership Style, Organizational Culture and Motivation on Job Satisfaction and Performance of Kolaka District Government Employees.

Arifin, N. (2010). Analysis of Organizational Culture on Employee Work Commitments in Increasing Employee Organizational Performance. Journal of Economics \& Education, 7 (2).

Armstrong, M. \& Baron, A. (1998). Performance Management - The New. Realities. London: Institute of Personnel and Development.

Astuti, P. (2012). Effect of Competence, Self Efficacy on Teacher Performance Mediated Organizational Commitment. Students' Journal of Economic and Management, 1 (1).

Bello, SM. (2012). Impact of ethical leadership on employee job performance. International Journal of Business and Social Science, 3 (11).

Buil, I., Martínez, E., \& Matute, J. (2018). Transformational leadership and employee performance: The role of identification, engagement and proactive personality. International Journal of Hospitality Management.

Dewi, IGAKR, \& Surya, IBK (2017). Effect of Organizational Culture on Organizational Commitment and Organizational Silence at PT. PLN (Persero) Rayon Denpasar.

Ghorbanpour, Z., Dehnavi, HD, \& Heyrani, F. (2014). Investigating the Effect of Organization Commitment on Performance of Auditors in the Community of Certified Accountants. Interdisciplinary Journal of Contemporary Research in Business, 5 (10), 199-209.

Gibson, James L., John M. Ivancevich \& James H. Donnelly. (2000), Organizational Behavior, Structure, Processes, 10th Edition, New York, McGraw-Hill

Hadiyatno, D. (2012). Effect of Competence, Compensation, and Job Satisfaction on Employee Performance at PT. Ciomas Adisatwa Balikpapan (Effect of Competence, Compensation, and Job Satisfaction of Employee Performance at PT Ciomas Adisatwa Balikpapan). Proceedings of Seminas, 1 (2).

Hamzah, MI, Othman, AK, Hashim, N., Rashid, MHA, \& Besir, SM (2013). Moderating the effects of organizational culture on the links between leadership competencies and job role performance. Australian Journal of Basic and Applied Sciences, 7 (10), 270-285.

Hasibuan, Malayu. (2006). Human Resource Management, Bumi Aksara. Jakarta.

Hersey, P., \& Blanchard, KH (1969). Life cycle theory of leadership. Training \& Development Journal.

Koech, PM, \& Namusonge, GS (2012). The effect of leadership styles on organizational performance at state corporations in Kenya. International Journal of Business and Commerce, 2 (1), 1-12.

Koesmono, HT (2006). The influence of organizational culture on motivation and job satisfaction and employee performance in the sub-sector of the medium-scale wood processing industry in East Java. Management and entrepreneurship journal, 7 (2), 171-188. 
Koesmono, HT (2007). The influence of leadership and task demands on organizational commitment with moderating variable motivation of nurses in Surabaya private hospitals. Journal of Management and Entrepreneurship, 9 (1), 30-40.

Kreitner, Robert. \& Kinicki, Angelo. (2003). Organizational behavior. Book 1. Salemba Empat. Jakarta

Lambert, EG, Qureshi, H., Frank, J., Klahm, C., \& Smith, B. (2018). Job stress, job involvement, job satisfaction, and organizational commitment and their associations with job research. Journal of Police and Criminal Psychology, 33 (2), 85-99.

Lumbanraja, P. (2009). Effect of Individual Characteristics, Leadership Style and Organizational Culture on Job Satisfaction and Organizational Commitment (Study on Local Governments in North Sumatra Province). Journal of Management Applications, 7 (2), 450-468

Luthans, Fred. (2006), Organizational Behavior. Ten Edition, PT. Andi. Yogyakarta.

Mangkunegara, .A. Anwar Prabu. (2005). Human Resource Management. Company, PT. Teenager Rosdakarya. Bandung.

Marshall, JR (2003). Two standards of competency are better: Why some defendants are not competent to stand trial should be permitted to plead guilty. U. Mich. JL Reform, 37, 1181.

Moeheriono. (2012). Competency-Based Performance Measurement. Jakarta: Raja. Grafindo Persada.

Natassia, R. (2013). Effect of Organizational Commitment and Compensation on Employee Job Satisfaction on CV. Lakitan Padang. JOURNAL OF ECONOMICA: Research of Economic And Economic Education, 1 (2), 175 -182.

Nimran, Umar. (2004). Organizational Behavior, Third Printing, CV. Citra Media, Surabaya.

Pandaleke, D. (2016). Effect of competence, job satisfaction and organizational commitment on employee performance (Study at the Southeast Minahasa District Inspectorate). EMBA Journal. Vol. 4 No, 2.

Panjisadewa, A. (2015). Effect of Leadership and Motivation on the Service Commitment of Tphp2kp in Belitung Regency (Doctoral dissertation, Bogor Agricultural University (IPB)).

Permata, NA (2017). Effect of Leadership Style on Employee Performance Through Organizational Commitment As Intervening Variables at Mayangan Jogoroto Jombang Health Center (Doctoral dissertation, University of Muhammadiyah Malang).

Republic of Indonesia. (2011). Government Regulation Number 46 of 2011 concerning Civil Servants Job Performance Assessment. Jakarta: State Civil Service Agency of the

Republic of Indonesia. (2013). Regulation of the Head of State Civil Service Agency Number 1 of 2013 concerning Assessment of Civil Servants' Work Performance. Jakarta:State Personnel Agency

Rivai, Veithzal \& Sagala, EJ (2004). Management of human resources for companies. Jakarta: PT Raja Grafindo Persada.

Rivai, Veithzal. (2009). Human Resource Management For Companies From Theory to Practice. Jakarta: Raja Grafindo Persada

Robbins, Stephen P. \& Timothy A. Judge. (2008). 12th Organization Behavior, Jakarta: Salemba Empat.

Roe, RA (2001). Competencies and competence management. Critique and proposal for a comprehensive theorybased approach. In the 10th European Congress for Work \& Organizational Psychology, Prague.

Russell, RF, \& Gregory Stone, A. (2002). A review of servant leadership attributes: Developing a practical model. Leadership \& Organization Development Journal, 23 (3), 145-157.

Sahara, F., Ratna, R., \& Matriadi, F. (2018). Effect of Leadership Style, Organizational Culture and Work Motivation on Employee Performance with Job Satisfaction as Intervening Variables at the Regional Secretariat of the City of Banda Aceh.Indonesian Management Journal (J-MIND),2(1), 140-156.

Sari, RN, \& Sjahruddin, H. (2018). Effect of Competence on Performance Moderated Employee Professionalism.

Shalahuddin, A. (2016). Effect of Leadership and Work Environment on Organizational Commitment and Employee Performance of PT. Djantin Source in West Kalimantan. Journal of Theory and Applied Management Journal of Theory and Applied Management, 6 (2).

Simamora, Henry. (2004). Human Resource Management, Third Edition ,. Yogyakarta, STIE YPKN 
Suriadi., Gani, M. U., Muh, N. H., \& Arifin, Z. (2018). The mediating role of organizational commitment of job performance: The Impacts of Leadership, job competency and organizational culture. Archives of Business Research, 6(11), 61-72.

Sjahruddin, H., \& Sudiro, AA (2013). Organizational justice, organizational commitment and trust in manager as predictor of organizational citizenship behavior. Interdiciplinary J. of contemporary Res. Bus. (IJCRB), 4 (12), 133141.

Soedjono, S. (2005). The influence of organizational culture on organizational performance and job satisfaction of employees at public passenger terminals in Surabaya. Journal of Management and Entrepreneurship, 7 (1), 22-47.

Soemantri, ST, \& Sjamsi, N. (2018). Analysis of the Effect of Work Motivation, Competence, and Compensation on the Performance of Police Members in the Kapuas Resort Police Unit in Central Kalimantan Province. Scientific Journal of Business Economics, 4 (2).

Spencer, LM, \& Spencer, SM (1993). Competence at work New York.

Sriekaningsih, A., \& Setyadi, D. (2015). The Effect of Competence and Motivation and Cultural Organization towards Organizational Commitment and Performance on State University Lecturers in East Kalimantan Indonesia. European Journal of Business and Management, 7 (17), 208-220.

Stander, MW, \& Coxen, L. (2017). A Review of the Relationship Between Positive Leadership Styles and Psychological Ownership. In Theoretical Orientations and Practical Applications of Psychological Ownership (pp. 37-60). Springer, Cham.

Steffens, NK, Fonseca, MA, Ryan, MK, Rink, FA, Stoker, JI, \& Pieterse, AN (2018). How feedback about leadership potential impacts ambition, organizational commitment, and performance. The Leadership Quarterly.

Tanuwibowo, JC, \& Sutanto, EM (2014). Relationship between organizational culture and organizational commitment to employee performance. Trikonomika Journal, 13 (2), 136-144.

Taurisa, CM, Djastuti, I., \& Ratnawati, I. (2012). Analysis of the influence of organizational culture and job satisfaction on organizational commitment in improving employee performance (Study at PT. Sido Muncul Kaligawe Semarang) (Doctoral dissertation, Diponegoro University).

Toban, C., \& Sjahruddin, H. (2016). The antecedent and consequence of Organizational Commitment and Job Satisfaction. Journal of Business and Management Sciences, 4 (2), 26-33.

Ulrich, D., Younger, J., Brockbank, W., \& Ulrich, M. (2012). HR from the outside in: Six competencies for the future of human resources. New York: McGraw-Hill.

Usmany, TP, Hamid, D., \& Utami, HN (2016). The Influence of Organizational Culture on Organizational Commitment and Employee Performance (Study on Gondorukem and Turpentine Factory Employees of Breadfruit Perum Perhutani Independent Business Units of Gondorukem and Turpentine II Industry, Ponorogo) Business Administration Journal, 37 (2), 38-44.

Van Esch, E., Wei, LQ, \& Chiang, FF (2018). High-performance human resource practices and performance: The mediating role of employees' competencies and the moderating role of climate for creativity. The International Journal of Human Resource Management, 29 (10), 1683-1708.

Wallace, RJ (2007). Reasons, relations, and commands: Reflections on Darwall. Ethics, 118 (1), 24-36.

Wibowo. (2014). Performance Management, Fourth Edition, Rajawali Pers, Jakarta.

Willy Susilo. (2010). Human Resource Audit, PT. Vorqistatama Jakarta

Yamali, FR (2017). Effect of Compensation and Competence on Organizational Commitment and Its Implications on the Performance of Construction Services Company Experts in Jambi Province. ECONOMICS: Journal of Economics and Business, 1 (1), 213-222.

Yanow, D., \& Adams, GB (2018). Organizational culture. In Defining public administration (pp. 137-146). Routledge.

Yeh, H., \& Hong, D. (2012). The mediating effect of organizational commitment on leadership type and job performance. The Journal of Human Resource and Adult Learning, 8 (2), 50.

Yuliawan, AK, \& Supartha, IWG (2012). The Effect of Leadership on Organizational Commitment, Job Satisfaction and Performance (Study on Employees in the Regional Secretariat of the City of Denpasar). E-Journal of Economics and Business at Udayana University.

Zohar, D. \& Marshall, I. (2000). SQ - Spiritual Intelligence the Ultimate Intelligence. London: Bloomsbury Publishing.

Zwell, Michael. (2000). Creating a Culture of competance. New York: John Wiley \& Sons, Inc. 